\title{
Lessons from the South Auckland Winter Milk Monitoring programme, 1989-1997
}

\author{
G.P. JONES ${ }^{1}$, M.W. AULD ${ }^{2}$ and W.J. HANSON ${ }^{1}$ \\ ${ }^{1}$ NZ Dairy Group, c/- AnchorMart, Whitaker St, Te Aroha 2971 \\ ${ }^{2}$ Agriculture New Zealand, PO Box 8, Pukekohe
}

\begin{abstract}
The performance of winter milk production systems, represented by between 7 and $17 \mathrm{New}$ Zealand Dairy Group suppliers in the South Auckland area, has been assessed for seven consecutive years. The monitoring programme has enabled comparison of winter milk systems with typical seasonal supply systems, and identification of management issues facing winter milkers. In 1995/ 96 the monitored farms had contract volumes ranging between 7 and 32 litres/ha (average 21 litres/ha). This reflected the total situation for all the NZDG winter milkers. Total annual production is also critical for profitability, and ranged between 684 and $1107 \mathrm{~kg}$ milksolids (MS)/ha in the year ending 31 August 1996 (mean $920 \pm 144$ kg MS/ha). The main requirements for successful winter milk production include planning and acting early for winter, in particular by:
\end{abstract}

1. early use of supplements in the autumn, including hay, silage and urea;

2. appropriate drying off of cows; and

3. grazing drystock off the home farm, so it can be effectively used as a milking platform.

Keywords: dairying, farm monitoring, South Auckland, winter milk

\section{Introduction}

The New Zealand Dairy Group (NZDG) winter milk supply zone is concentrated around the South Auckland area - Clevedon, Karaka, and Pukekohe - with a lesser proportion of milk supplies coming from further afield (Kaipara, Waiuku Peninsula, Maramarua, Hamilton, and, from 1 June 1997, the Bay of Plenty). Within the South Auckland zone there are different areas with different characteristics of topography, climate, soil types and farm services. For example, the sandy soils of the Waiuku Peninsula are suited to early winter (May-June) calving, and drying off before the typically very dry summers, and produce around $11000 \mathrm{~kg}$ pasture DM/ha/year. In contrast, the wetter swamp soils of Otaua by the Waikato River mouth suit late calving around 20 August, and milking on through the relatively strong summer growing conditions. Estimated pasture production there is 15000 $\mathrm{kg} \mathrm{DM} / \mathrm{ha} / \mathrm{year}$, and is slightly lower in the Karaka area. In essence, then, farmers have taken advantage of the diversity in order to produce winter milk by different management systems. The NZDG in turn has a certain security of supply through the winter. However, this same variability also leads to some difficulties in comparing performance per hectare and per cow at the farm level.

Most winter milk supplies (83\%) come from farmers operating autumn- or split-calving systems; that is, all or a proportion of their herds calve in autumn, with the balance in spring. The actual proportion of autumn calvers depends on the contract volumes. Other systems involve early-winter calving (late May-early June, $8 \%$ of farms), or late-winter calving (mid-AugustSeptember, 9\%).

The Winter Milk Monitoring programme was established in order to:

1. assess the profitability of winter milk production systems, particularly in relation to seasonal supply systems in the same region; and

2. generally report on management issues for the monitored farms, and for winter milk contractors in general.

Representative farms were selected for monitoring, and production, financial and management data were collected at regular intervals. Over the seven years of monitoring from 1 September 1989, up to 17 farms participated in any one year, of a total 19 contributors.

Seasonal supply information was also collated for comparison, and relates to the MAFPolicy WaikatoSouth Auckland Farm Monitoring dairy farm.

This paper presents the key management issues for all farms, and the detailed results for the seven who contributed every year.

\section{Characteristics of the Winter Milk Monitoring farms}

Some difficulties were experienced in selecting sufficient farms and farmers who met the criteria deemed necessary for monitoring: 
1. representative production system;

2. farmer ability to talk about their systems to both the consultants collating the information, and to likely future field-days held to discuss the findings; and

3. good financial and farm management recordkeeping.

Almost by default, the Winter Milk Monitoring farmers comprised a well-above-average sample of all winter milk producers: the seven who have participated in all of the last six years of monitoring produced 34\% more milksolids/ha (920 kg MS/ha) in the 1995/96 year (ending 31 August 1996) than the average winter milk producer (721 kg MS/ha), 37\% more than the average Pukekohe district producer (670 kg MS/ha), and 16\% more than the NZDG average supply (790 kg MS/ha) (Figure 1).

Figure 1 Production/ha of WM monitoring farms versus other company groups.

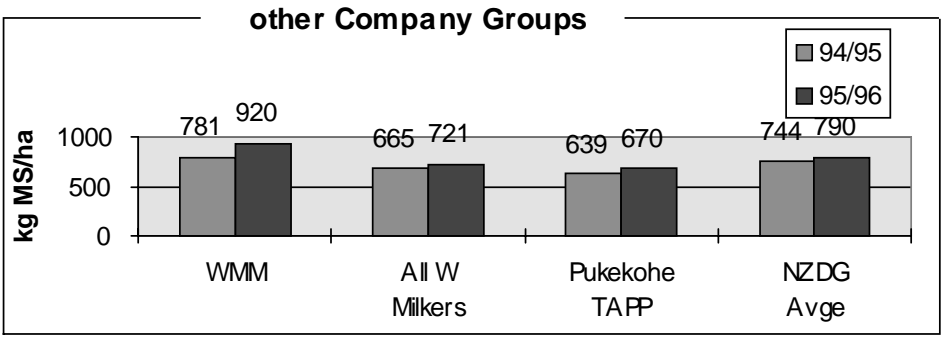

\section{Results}

Table 1 outlines the 1995/96 achievements of those who participated in every monitoring year, and reflects the results found for all of the last four years.

In 1995/96 the monitored farms had contract volumes ranging between 7 and 32 litres/ha, with an average of 21 litres/ha. This reflected the total situation for all the NZDG winter milkers, where there is a moderate bias towards autumn calving, with 20-25 litres/ ha contract, and overall stocking rates of around 2.5 cow equivalents/ha.

Total annual production is also critical for profitability, and ranged between 684 and $1107 \mathrm{~kg}$ MS/ ha in the year ending 31 August $1996(920 \pm 144 \mathrm{~kg}$ MS/ha). Production levels are summarised in Figure 1 and Table 1.

The seasons have been characterised by:

1. wet springs - poor growth until October-November

2. dry March-April periods

3 . wet winters.
Cold, wet winters have a number of effects on total profitability and make winter milkers more vulnerable than seasonal suppliers:

1. total seasonal production is down, especially if there are reduced cow numbers carrying through to the spring;

2. fewer cows calve over a longer period in the following autumn, because of poor feed growth, utilisation, and feed stress affecting breeding programmes;

3. there can be loss of contract volumes owing to failure to meet agreed contract supplies. Maintenance of contract volumes from the herd without damaging pastures can only lead to off-paddock feeding and inevitably big increases in feed costs;

4. non-weather factors outside the farmer's immediate control can also make some winter milk contract operations vulnerable. The experiences of some top operators with poor breeding supplies (technicians and/or semen) in 1993/ 94 emphasised how apparently good systems can be drastically affected by problems with re-breeding at the extremes of the season. Climatic variations can be responded to, and justified with the payment of a winter milk premium, but breeding problems cannot be allowed for in the same way.

Over the years, and especially after the very wet 1995 winter, farmers have generally aimed to enter the winter with better pasture covers, and have reacted more positively to the wet conditions. Actions taken to optimise feed utilisation and minimise pasture damage included:

1. more supplements, including nitrogen, are fed out earlier;

2. more supplements are fed off the paddock, on races, sacrifice areas, etc;

3. more cows spend time off the grass, being held on races and yards;

4. more culling is done earlier;

5. there is more grazing off of stock.

Major difficulties in winter 1995 related to:

- Foot problems and race deterioration increased as a result of the time spent off paddocks.

- cows lost condition: cow condition in the district overall was estimated at 0.75 unit lower in August 
Table 1 Data summary, 1995/96, winter milk monitoring.

\begin{tabular}{|c|c|c|c|c|c|c|c|c|c|}
\hline $\begin{array}{l}\text { Calving pattern } \\
\text { Name }\end{array}$ & $\begin{array}{c}\text { WMM } \\
\text { Avg } \\
\text { average }\end{array}$ & $\begin{array}{c}\text { Split } \\
\text { A }\end{array}$ & $\begin{array}{c}\text { Aut } \\
\text { B }\end{array}$ & Early & $\begin{array}{c}\text { Split } \\
\text { D }\end{array}$ & $\begin{array}{c}\text { Split } \\
\text { E }\end{array}$ & $\begin{array}{c}\text { Aut } \\
\mathrm{F}\end{array}$ & $\begin{array}{c}\text { Split } \\
\text { G }\end{array}$ & $\begin{array}{l}\text { MAF } \\
\text { SS } \\
\text { Seas } \\
\text { Supply }\end{array}$ \\
\hline Home farm ha & 78 & 75 & 42 & 38 & 75 & 81 & 165 & 70 & 70 \\
\hline \multicolumn{10}{|l|}{ Cow equiv/home ha } \\
\hline avge whole year & 2.23 & 1.56 & 2.01 & 2.76 & 2.51 & 2.60 & 2.23 & 1.96 & 3.00 \\
\hline avge in May-July & 2.21 & 1.23 & 2.47 & 2.74 & 2.50 & 2.16 & 2.51 & 1.89 & 2.74 \\
\hline $\begin{array}{l}\text { peak cow eq./ha } \\
\text { month of peak cow }\end{array}$ & 2.74 & 2.30 & 2.79 & 3.11 & 2.83 & 3.29 & 2.50 & 2.36 & \\
\hline equiv. & & Mar & Jul & Aug & Jan & Dec & Aug & Jun & \\
\hline \multicolumn{10}{|l|}{ During WM contract } \\
\hline Cows/ha milked $\left({ }^{*}\right)$ & 1.65 & 0.92 & 1.92 & 1.21 & 2.24 & 1.82 & 2.06 & 1.36 & 0 \\
\hline Winter milk period & & $\begin{array}{l}1 \text { May - } \\
31 \text { July }\end{array}$ & $\begin{array}{l}1 \text { May - } \\
31 \text { July }\end{array}$ & $\begin{array}{l}11 \text { Jun - } \\
31 \text { July }\end{array}$ & $\begin{array}{l}1 \text { May - } \\
31 \text { July }\end{array}$ & $\begin{array}{l}1 \text { May - } \\
31 \text { July }\end{array}$ & $\begin{array}{l}1 \text { May - } \\
31 \text { July }\end{array}$ & $\begin{array}{l}1 \text { May - } \\
31 \text { July }\end{array}$ & 0 \\
\hline Milkfat kg/ha & 514 & 394 & 544 & 590 & 546 & 617 & 455 & 453 & 426 \\
\hline kg MS/ha & 920 & 684 & 958 & 1014 & 1068 & 1107 & 813 & 798 & 750 \\
\hline Litres total/ha & 11716 & 8041 & 12313 & 11320 & 15517 & 14493 & 10248 & 10077 & 8832 \\
\hline \multicolumn{10}{|l|}{ WM contract } \\
\hline litres/ha & 21 & 11 & 24 & 7 & 32 & 28 & 30 & 18 & 0 \\
\hline \multicolumn{10}{|l|}{ Winter milk as a $\%$} \\
\hline of total litres & 17 & 12 & 18 & 6 & 19 & 18 & 27 & 16 & 0 \\
\hline
\end{tabular}

(autumn calvers down 0.5, spring calvers down 1). This and feeding problems meant empties averaged $20-25 \%$ in 1994/95, versus an average of $15 \%$. More cows were thinner in the summer 1994, so submission rates were down at the first round of mating. The rapidly decreasing rates of nutrition since then, reflected in the declines in production/ cow from 1 May 1995, further exacerbated the rebreeding problem.

A few autumn-calving herds were on once/day milking in August 1995. All 191 autumn-spring calving farms collectively supplied $12.2 \%$ above contract in June, and $0.86 \%$ under contract in July, when over the previous three years they had supplied $15 \%$ above contract throughout the winter. The results served to emphasise the need for a steady to rising nutrition status through June-July if reasonable production and breeding performance are to be achieved.
The 1996 winter was also very wet, and farmers adopted the same actions as above, but earlier and with much less bought-in feed.

Carryover effects of very wet winters continue into the following season, as feed and body reserves are replenished, and races and pastures are repaired.

Split-calving operations are complicated systems compared to seasonal supply. They require careful management of feeding, and assessment of weather issues. A major trap for some split calvers and allautumn calvers occurred when the autumn calving system became disorganised. The result was that farmers were reliant on late lactation spring calvers for the provision of contract volumes. Fresh-calving autumn and spring herds were then not calving onto enough feed, contributing to a repeat of the situation the following year. Much lower annual total production and income then resulted.

Split calvers are also concerned about: 
1. the high costs of the spring-calving cows associated with winter grazing and their relatively short lactations in many seasons; and

2. the complexity and seemingly unrelenting nature of the system.

Therefore a number of suppliers are now becoming more interested in all-autumn calving systems.

\section{Conclusions}

To achieve high total and winter contract production levels, successful winter milk production relies on three main practices:
1. early use of supplements in the autumn, including hay, silage and urea;

2. appropriate drying off of cows; and

3. grazing of drystock off the home farm, so it can be effectively used as a milking platform.

While there has been variability in the results achieved by the monitoring farms, and winter milk producers generally, those who have succeeded are planning and acting early, as well as increasing feed on the farm in the winter by use of practices 1 to 3 above. 